\title{
The Duke's Favourites: Towards a Gendered View of the Politics of Concubinage at the Early Modern Court
}

\author{
Regine Maritz ${ }^{1}$
}

On the 14th of February 1608 Duke Johann Friedrich of Württemberg received a letter from Michael Koch, deputy bailiff (Untervogt) in Blaubeuren. It contained alarming information about two women, Magdalena Möringer and Catharina Weickhmann and their connection to the affairs of the administrative district of Blaubeuren:

the bailiff (Obervogt) was never present here, for in three quarters of last year just passed he did not sit for more than three or four days in office[;] but the old woman [Möringer] and the young woman [Weickhmann] took over official business too much and they let it be known publicly, that they were installed as the highest regents here, [that they] had power and influence, [that] if one person or another was to act against them they would have him thrown into the bottom of the tower and feed him on water and bread, which is how they awoke great terror and fear in people. ${ }^{2}$

Who were these fearsome women of whom Koch spoke, and how did they earn such doubtful acclaim? Chancellors of the Württemberg court spoke about Möringer in a great number of documents produced in the months and years after Duke Johann Friedrich of Württemberg (1582-1628), succeeded his father Duke Friedrich I when the latter died unexpectedly in January 1608. In July 1608, privy councillor Melchior Jäger wrote a long report, which began as follows:

Highborn prince, merciful lord, your princely grace instructed me his privy councillor Melchior Jäger, because of the manifold past mistakes ... committed by your beloved

\footnotetext{
${ }^{1}$ I wish to thank Ulinka Rublack, Chris Marsh, Laura Kounine, Katy Bond, Tom Tölle, and the anonymous German History reviewers for their helpful comments on previous versions of this article.

2 Hauptstaatsarchiv Stuttgart (in the following: HStAS) A 48/10 Bü 1, letter by Michael Koch to Duke Johann Friedrich, doc. 6, 14 Feb. 1608, fol. 4v: 'vnnd ist der Obervogt nimmer anheimisch gewesen, Inn=maßen er auch in den drein viertel Jar hero, über drei oder vier ampt täg mit mir nit besessen, die alt: vnnd jung frauw aber, haben sich der ampts sachen nur zuuil angenommen, vnd sich offentlich vernemmen lassen, daß sie zu den öbersten Regentinen hiehero gesetzt seyen, macht vnnd gewallt haben, einen oder den andern, der wider sie handlen thüe, in Thurminboden [sic] zuuerffen, vnd mit wasser vnnd brot abzuspeißen, dahero sie ein großen, schreckh vnd forcht, vnder den Leiten erweckht haben', translation is my own, as are all following.
} 
father ex humania imbecilitate[out of human weakness], to advise out of submissive duty what could be done for the satisfaction of the commandments of God, [for] the distribution of justice, [for] the maintenance of your father's princely reputation, and [for] the common good ... ${ }^{3}$

The document identifies Möringer as a procuress and a number of other women as former mistresses of Duke Friedrich. Yet only Möringer was imprisoned and held for six years, and continually prosecuted for several years thereafter. Despite this decisive action against her, she could not be charged officially with adultery nor with being a procuress. In order to make such accusations two or three parties would have had to have been named, and Duke Johann Friedrich could not implicate his father in such a lawsuit, even posthumously. For Möringer this meant that her belongings were confiscated and that she was imprisoned without a clear understanding of the procedures that would follow. During her imprisonment, she wrote letters, supplications, apologies, and prayers whenever she could, although the Stuttgart councillors tried to stop these endeavours. Over many years, she insisted that she did not understand why she was being held in captivity, and that she had been misled by the woman whose house she inhabited in Urach. She only rarely mentioned her contact with the late duke in her writing, and when she did she insisted: 'I do not know anything, except that he liked to look at the girls'. ${ }^{4}$ The 'girls' were three women, who had come to live with Möringer in Urach, at her invitation according to their later statements: ${ }^{5}$ Catharina Weickhmann (née von Miltitz), Ursula Weickmann and Cordula Ebner. ${ }^{6}$ In Magdalena Möringer's version of events, she thus admitted to housing women whom the late duke had visited regularly, although she was careful to remain vague about her own role in this arrangement.

\footnotetext{
3 HStAS, G 60 Bü 9, Gutachten, 7 July 1608, 1r, ‘Durchleichtiger hochgeborner Fürst, Genädiger herr, was E.F.G. durch mich dero geheimen Rhatt Melchior Jäger, ec. wegen bey dero vilgeliebten herren Vatters hochseligen angedenckhens, ex humania imbecillitate vorgelauffner vilfälttiger fehler, ...den subsignirten genädig vorhalten vnd begehren lassen, hierinnen derßelben was zur Satisfaction der gebott Gottes, ertheillung der Justitien, erhalttung dero herren Vaters fürstliche, reputation auch allgemeinen weßen zum besten vnnd dienlichsten vnderthenig pflicht schuldiger weiß rathlich zu sein', original cursives.

${ }^{4}$ HStAS, A 48/10 Bü 3, 'Gebetbüchlin', 'weis nichs dan das er die metlain hat geren gesehen'.

${ }^{5}$ For instance HStAS, A 48/10 Bü 2, doc. 66, 13 Sept. 1608.

${ }^{6}$ There was also a maid named Maria Pirner, but she appears to have been there purely as a help to the older women living in the house.
} 
The activities of these women, documented during Möringer's prosecution, form the core of this article. But what can this protracted tale teach us, except that the dukes of Württemberg entertained mistresses long before the famous cases of Wilhelmina von Grävenitz (1685/6-1744) and Franziska von Hohenheim (1748-1811)? This case invites us, I will suggest, to expand our view of how gender should be used as an analytical tool for studying early modern courtly politics. Cases of concubinage are of course frequently discussed by scholars concerned with women's and gender history, since they can provide insights into how women could share in practices of power through their access to rulers and through building networks of patronage. ${ }^{7}$ This article, however, will be concerned with what the gender relations expressed within concubinage meant for the early modern court as a polity with extensive representative needs. Attention will be focused on the more institutionalised form of concubinage that is here represented by Möringer and her household of women, as opposed to ephemeral extramarital affairs. It will be argued that it is specifically the former that has an important political dimension. The work presented here forms part of a larger study that seeks to analyse the role of gender difference in dynastic and court politics in early modern Württemberg, and that suggests that gender was not simply a relational category affecting who could participate in early modern politics and how, but that it was in itself a crucial and active resource of dynastic power. ${ }^{8}$ This new reading of early modern practices of power is elucidated using the court of Stuttgart and its rich records as a case study.

Möringer's prosecution will be read alongside the case of Duke Friedrich's male favourite Matthäus Enzlin, which ran simultaneously to the Möringer case in Württemberg, but which has received disproportionately more scholarly attention to date. It will be argued that it makes sense to analyse the roles of male and female favourites with similar conceptual approaches, for although their tasks in the service of the prince varied, they were both

\footnotetext{
${ }_{7}^{7}$ See for instance C. Hanken, Vom König geküßt.: Das Leben der großen Mätressen. (Berlin, 1999); S. OßwaldBargende, Die Mätresse, der Fürst und die Macht: Christina Wilhelmina von Grävenitz und die höfische Gesellschaft (Frankfurt/Main; New York, 2000); K. Wellman, Queens and Mistresses of Renaissance France (Yale, 2013). 8 See R. Maritz, 'Gender as a Resource of Power at the Early Modern Court of Württemberg, c. 1580-1630' (Ph.D., Cambridge 2018); The methodological approach to this study as well as the present article is adapted from M. Mommertz's 'tracer concept' of gender. See 'Theoriepotentiale ,ferner Vergangenheiten': Geschlecht als Markierung/Ressource/Tracer', L'Homme, 26, 1 (2015), pp. 79-98.
} 
vulnerable to accusations of disturbing the divinely approved political order. ${ }^{9}$ Nevertheless, the category of gender cannot be abandoned in the study of concubinage, since it was a profoundly gendered practice in the sense that its exercise was open to dynastic men alone. I argue that this distinct discrepancy between what counted as acceptable behaviour for the two partners within the ruling couple can give us further insight into the gendered nature of the hierarchy of power that applied not only to the couple in question, but also to the entire duchy. In practicing concubinage, Duke Friedrich contravened the Lutheran prescription of monogamy, and he marked himself out as the only member of the courtly household whose position was truly unique. The duke's actions highlighted the fact that even some of the functions of the duchess, Sibylla of Württemberg, were not exclusive to her, but might be distributed across several women.

\section{I: Male and Female Courtly Favourites}

Historians who discuss male favourites find it crucial to analyse the underlying structural and political reasons that created an environment in which they could develop their careers. Increasingly complex bureaucracy, a drive for centralisation, and a ruler with something to prove have all been identified as political problems that a skilled male favourite might be able to navigate, and all of these issues were present at the court of Duke Friedrich I of Württemberg. ${ }^{10}$ For these studies, it is a matter of course to investigate exactly how male favourites slotted into the early modern practice of power, and at what point their dealings came to be viewed as problematic. The historiographical discussion of mistresses and female favourites, however, has, at times, taken a different approach, as we shall see.

\footnotetext{
9 R. G. Asch, 'Corruption and Punishment? The Rise and Fall of Matthäus Enzlin (1556-1613), Lawyer and Favourite', in J. Huxtable Elliott and L. W. B. Brockliss (eds.), The World of the Favourite (New Haven and London, 1999), pp. 106-108, identifies the disturbance of established order as a key transgression of the (male) favourite. 10 See R. G. Asch, 'Schlußbetrachtung. Höfische Gunst und höfische Günstlinge zwischen Mittelalter und Neuzeit. 18 Thesen', in J. Hirschbiegel and W. Paravicini (eds.), Der Fall Des Günstlings: Hofparteien in Europa vom 13. bis zum 17. Jahrhundert (Ostfildern, 2004), p. 522f.; O. Auge, 'Holzinger, Enzlin, Oppenheimer. Günstlingsfälle am spätmittelalterlichen und frühneuzeitlichen Hof der Württemberger', in J. Hirschbiegel and W. Paravicini (eds.), Der Fall des Günstlings: Hofparteien in Europa vom 13. bis zum 17. Jahrhundert (Ostfildern, 2004), 373; Hirschbiegel, 'Zur theoretischen Konstruktion der Figur des Günstlings', p. 31.
} 
Matthäus Enzlin (1556-1613) was a professor of law at Tübingen University and simultaneously served as one of Friedrich I's most important councillors. ${ }^{11}$ Enzlin's legal expertise helped Friedrich to curtail the influence exercised by the Württemberg diet, which consisted of the burgher representatives of the administrative district of the territory (Amtmänner), as well as the prelates. The local nobility was excluded from the assembly, since they submitted only to the authority of the emperor. ${ }^{12}$ Nevertheless, the diet was a force to be reckoned with since its members had been granted extensive rights of co-determination on taxes in the treaty of Tübingen in 1514, and Enzlin's strengthening of ducal power decisively reordered this political configuration. ${ }^{13} \mathrm{He}$ was replaced in his role as closest advisor almost immediately after Friedrich's death. In May 1608, Enzlin was arrested and charged with corruption and later with treason; in 1613 he was executed. ${ }^{14}$ From 1610, Enzlin was imprisoned in the same fortress as Möringer and Möringer's letters show that the two prisoners knew of each other and that she attempted to observe the comings and goings in his room. ${ }^{15}$

Duke Friedrich had created a dazzling, international court that provided a setting for proto-scientific research, artistic endeavours, and magnificent festivities the likes of which had never been seen before in Stuttgart. ${ }^{16}$ He subscribed to an explicitly mercantilist policy and laboured to strengthen the mining and textile industries in Württemberg. ${ }^{17} \mathrm{His}$ dealings with his estates clearly reveal that he felt entitled to more independent authority over financial and political decisions than the dukes of Württemberg had previously claimed. ${ }^{18}$ Differences with

\footnotetext{
11 W. Grube, Der Stuttgarter Landtag: 1457 - 1957: Von den Landständen zum demokratischen Parlament (Stuttgart, 1957), p. 251.

12 Ibid. on Enzlin's exploits in the diet, pp. 263-273, and J. Allen Vann, The Making of a State: Württemberg 15931793 (Ithaca, N.Y, 1984), ch. 1 'The Shape of the Duchy', pp. 24-57, gives a very useful overview of the local estates. 13 Ibid., p. $45 f$.

14 Grube, Der Stuttgarter Landtag, pp. $276 f$.

15 HStAS, A 48/10 Bü 3, letter from Möringer, 19May 1610.

${ }^{16}$ See U. Rublack, The Astronomer and the Witch: Johannes Kepler's Fight for His Mother (Oxford, 2015), ch. 2 'A Lutheran court', pp. 45-65; Paul Sauer, Herzog Friedrich I. von Württemberg 1557-1608: ungestümer Reformer und weltgewandter Autokrat (München, 2003), pp. 136-145.

${ }_{17}$ S. Lorenz, 'Herzog Friedrich I. Von Württemberg (1557-1608): ein Fürst zwischen Ambition und Wirklichkeit. Zur Einführung', in Joachim Kremer, Susanne Borgards, and Ulrich Günther, (eds.), Hofkultur um 1600: die Hofmusik Herzog Friedrichs I. von Württemberg und ihr kulturelles Umfeld (Ostfildern, 2010), p. 15.

${ }_{18}$ Grube, Der Stuttgarter Landtag, p. 251, explains Friedrich's authoritarian tendencies with his provenance from a different 'country'. Friedrich had been born as Count of Mömpelgard, which was a Württemberg enclave on the left side of the Rhine on French soil. Friedrich ruled there for nearly a decade before the main Württemberg line failed with the death of the childless Duke Ludwig.
} 
the estates started to emerge about two years after Friedrich took power in 1593. In 1595 the duke demanded the levying of a second round of Türkenhilfe from the estates, and when they tried to resist, Friedrich's response was excessively sharp and authoritarian, so much so that the estates were cowed into agreement. ${ }^{19}$ Besides intimidation tactics, Friedrich also slowly began to introduce officials who were deeply loyal to him to bailiwicks in his territory and ousted prelates who had previously voted against his propositions. The effect was that the assemblies of the estates were increasingly filled with men who supported the ducal government. This helped Friedrich and his favourite Enzlin to push through their enormous financial demands and to quash resistance. ${ }^{20}$

Ronald Asch has analysed Enzlin's career and subsequent fall from grace in an article that identifies him as a relatively typical case of a courtly favourite. ${ }^{21}$ Asch emphasised that as a legal scholar Enzlin was perfectly suited to this role, at a time when 'the duke needed somebody who was able to transform his quest for power into legal arguments' ${ }^{22}$ By comparing Enzlin's relationship with the duke with those of other court officials, Asch shows that Enzlin's influence was extraordinary. ${ }^{23}$ For historians, Enzlin's case is difficult to analyse for similar reasons that complicated the case of Möringer's household and the duke's mistresses: it was hazardous for Duke Johann Friedrich to state that his father had fallen under excessive influence from one councillor, and thus some of the underlying reasons why Enzlin came to be arrested were never explicitly stated. Instead, Enzlin was accused of financial misdealings and corruption. Asch reads the trial as symptomatic of a wider drive amongst seventeenth-century German territories towards the institutionalisation of a practice of governance in which the will

\footnotetext{
${ }^{19}$ Türkenhilfe was a tax levied by the Emperors of the Holy Roman Empire from the fifteenth century onwards, in order to help them meet the military challenges posed by the Ottoman Empire. In this case, the money was to help finance the Long Turkish War (1593-1606).

20 The most important example being the 400 '000 Gulden they won from the estates to purchase suzerainty from Prague. This was one of the most significant victories won by Friedrich, since it meant that Württemberg would no longer revert to the control of the Holy Roman Emperor should its male line come to an end. Thus the territory gained more independence, at the very least in the minds of the subjects. See Grube, Der Stuttgarter Landtag, pp. 260-4.

21 Asch, 'Corruption and Punishment? The Rise and Fall of Matthäus Enzlin (1556-1613)', pp. 96-111.

22 Ibid., , p. 100.

23 Ibid., , pp. 101-104; also see: J. Hirschbiegel, 'Zur Theoretischen Konstruktion Der Figur Des Günstlings', in Jan Hirschbiegel and Werner Paravicini (eds.), Der Fall des Günstlings: Hofparteien in Europa vom 13. bis zum 17. Jahrhundert (Ostfildern, 2004), pp. 23-40, here p. $38 f$.
} 
of the regent was filtered through a bureaucratic system of formal councils and was ordinarily dispensed in collaboration with the estates. In this context, the informal and personal dealings of a Mathäus Enzlin could not be tolerated. In contemporary political debate, such courtly favourites were thought to disrupt the divine order through exercising influence that went beyond their appointed roles. ${ }^{24}$

Mistresses of noblemen and rulers, on the other hand, are typically regarded as 'symbol[s] of wealth, status, and power', who served an important emotional function for noblemen, providing married men with relationships based on personal choice in a society in which marriages were primarily based on rank and wealth rather than on the personal qualities of the spouse. ${ }^{25}$ The practice of concubinage could also relieve some of the inheritance pressure on the male line of the family, since any children born from such unions normally could not claim a stake in the dynastic line. ${ }^{26}$ The women who stood at the centre of such relationships have long been identified as a subject for historical investigation. Initially, it was their unusual life stories and the 'libidinous attachment' they inspired in powerful men that attracted the bulk of attention. ${ }^{27}$ More recently, however, historians have analysed these actors for their political influence, which often went above and beyond what contemporaries would have expected of persons of their social standing and gender. ${ }^{28}$ Since female favourites or mistresses have thus come to be recognised as political players who resist attempts to be reduced to their sexuality, the newer generation of court history has begun to treat them alongside male minister favourites. ${ }^{29}$ This

\footnotetext{
${ }^{24}$ As goes Asch's argument in: 'Corruption and Punishment? The Rise and Fall of Matthäus Enzlin (1556-1613)', pp. 106-8.

25 J. Hurwich, Noble Strategies: Marriage and Sexuality in the Zimmern Chronicle (Kirksville, Mo., 2006 ), p. 194.

${ }^{26}$ Ibid., also see M. Sikora, 'Eléonore d'Olbreuse - die Herzogin auf Raten', in K. Biercamp and J. Schmieglitz-Otten (eds.), Mächtig verlockend : Frauen der Welfen (Berlin, 2010), pp. 16-43, here esp. pp. 21-28.

27 Though the titillating details of the lives of mistresses remain even now a popular topic. See for instance J. Walter, Lust und Macht : Mätressen an deutschen Höfen (Mühlacker, 2010).

${ }^{28}$ See for instance, Oßwald-Bargende, Die Mätresse, der Fürst und die Macht; Wellman, Queens and Mistresses of Renaissance France, who shows, for instance, that royal mistresses regularly took over some of the representational tasks that were usually appointed to the queen, see pp. 36, 113f., 124.

${ }^{29}$ See for instance A. Pečar, 'Strippenzieher im Verborgenen. Favoriten und Mätressen und die politischen Entscheidungsstrukturen an den Fürstenhöfen der Frühen Neuzeit', in Volkhard Huth (ed.), Geheime Eliten?: Bensheimer Gespräche 2010/11 Veranstaltet vom Institut für Personengeschichte (Bensheim) in Verbindung mit der Ranke-Gesellschaft (Köln) (Frankfurt am Main, 2014),pp. 269-286; L. Horowski, Die Belagerung des Thrones. Machtstrukturen und Karrieremechanismen am Hof von Frankreich 1661-1789 (Ostfildern, 2012), esp. pp. $274-277$.
} 
development is to be welcomed, for, as the cases of Matthäus Enzlin and Magdalena Möringer will show, male and female favourites raised similar anxieties in contemporaries. ${ }^{30}$

Nevertheless, a complete conceptual conflation of the male and female favourite is to be avoided. For if we broaden our perspective to include both the favourite and the ruling couple, it emerges that concubinage was a highly gendered practice in the sense that it was available to aristocratic men alone, whilst noblewomen could expect drastic sanctions for even the perceived loss of chastity, not to mention actual adultery. ${ }^{31}$ When social and cultural norms are so clearly deployed to erect gender-specific barriers, there is always power at stake. With concubinage, as with other male-coded aristocratic practices such as the hunt and fighting with weapons, practicing with panache and with appropriate overtones of conspicuous consumption meant emphasising and legitimizing one's unique position of power.

\section{II: Ruling Marriages}

In order to understand the potential political consequences of the gendered practice of concubinage more fully, we need to analyse both the dynamics of gendered power relationships at court, and the cultural and religious ideals that shaped contemporaries' expectations of them. With regard to the latter, Heide Wunder has shown how in the postreformation German lands, a lot of emphasis was placed on the idea of task-sharing between marital couples. ${ }^{32}$ In the context of dynastic rulership this mode of thinking about married 'working couples' led to the idea that wives would perform important cultural work at court, for example by extending patronage to artists, and setting the agenda in courtly fashion. This cultural work would help to garner legitimacy for the current regime. At Protestant courts in

\footnotetext{
${ }^{30}$ See also L. Levy-Peck, 'Monopolizing Favour: Structures of Power in the Early Seventeenth-Century English Court', in John Huxtable Elliott and L.W.B. Brockliss (eds.), The World of the Favourite (New Haven, Conn., 1999), pp. 54-70, here p. 63, who argues that the common point which all favourites shared was a level of intimacy with the ruler.

${ }^{31}$ See F. Geyken, "'Ohne seiner frau todt witwer zu werden, ist doch etwas rares". Folgen des ehelichen Ungehorsams - Sophie Dorotheas Verbannung nach AhIden', in K. Biercamp and J. Schmieglitz-Otten (eds.), Mächtig verlockend : Frauen der Welfen (Berlin, 2010), pp. 166-185; S. Marra, Allianzen des Adels: dynastisches Handeln im Grafenhaus Bentheim im 16. und 17. Jahrhundert (Cologne, 2007), pp. 122-127.

${ }^{32}$ H. Wunder, 'Er ist die Sonn', Sie Ist der Mond': Frauen in der frühen Neuzeit (München, 1992), esp. pp. 96-8.
} 
particular, the centrality of the ideal of matrimony meant that the duality of the ruling couple was an important feature of both representational and practical efforts to continually reinvigorate rulership. ${ }^{33}$ This notion was further underpinned by the courtly institution of the Frauenzimmer: the representational household of the princess or duchess and the primary area of influence for the ruler's consort. ${ }^{34}$ Whilst the court mistress (Hofmeisterin) was contractually bound to the male ruler, she answered directly to the female consort regarding issues arising within this community. ${ }^{35}$ The Frauenzimmer in Württemberg comprised young noble children, as well as a handful of ladies-in-waiting who served as the consort's representative entourage. ${ }^{36}$ The inhabitants and servants of the Frauenzimmer ate, slept, and worked together: they composed a fully functioning household within the larger courtly setting. Noble families coveted the positions of ladies-in-waiting for their unmarried daughters, since such a court office brought them closer to the practice of power and could convey financial and symbolic capital. The young noble women became acquainted with courtly etiquette through their service to the consort, and a successful career in the Frauenzimmer was often followed by an advantageous marriage instigated by their mistress. ${ }^{37}$

Beyond an educational role for the next generation of the courtly elite, the Frauenzimmer was also a space for female-led piety and dynastic representation. ${ }^{38}$ At festive events at court, the consort and her Frauenzimmer appeared together at strategic moments in order to lend splendour and exclusivity to the proceedings. Both during high ceremonies and in everyday courtly life in the German lands, the gendered segregation of the most high-ranking members of the courtly households enhanced the standing of the ruling couple. This practice

\footnotetext{
${ }^{33}$ See the recent volume M. Schneikart and D. Schleinert (eds.), Zwischen Thronsaal und Frawenzimmer: Handlungsfelder pommerscher Fürstinnen um 1600 (Cologne, Weimar, Vienna,2017), with an introduction by Wunder that gives an up-to-date overview of this topic and the chapters span the broad range of contributions made by ruler's consorts to the practice of power, such as, the patronage of church, music, and creative arts, the upkeep of extensive communication networks, as well as the collecting of books and knowledge.

${ }^{34}$ See K. Katrin Keller, Kurfürstin Anna von Sachsen (1532-1585) (Regensburg, 2010),pp. 111-20.

35 HStAS, A 20 Bü 27, 'Ordnung der hofmeisterin zur frawenzimmer', 22 Mai 1577.

${ }^{36}$ HStAS, A 21 Bü 204, 'Setzordnung' 1582, lists three male noble pages and six noble ladies-in-waiting for the Frauenzimmer, the total number of inhabitants is 21 , which includes servants.

${ }^{37}$ K. Keller, 'Ladies-in-Waiting at the Imperial Court of Vienna from 1550 to 1700: Structure, Responsibilities and Career Patterns', in N. Akkerman and B. Houben (eds.), The Politics of Female Households: Ladies-in-Waiting across Early Modern Europe (Leiden, 2014), pp. 77-98, here esp. p. 90.

${ }^{38}$ See J. Bepler, 'Die Fürstin als Betsäule - Anleitung und Praxis der Erbauung am Hof', Morgen-Glantz, 12 (2002), pp. 249-264.
} 
underlined the chastity and purity of the duchess and her bloodline, and emphasised the status of the male ruler, since he was the only man at court who could demand access to the Frauenzimmer space any time he pleased. ${ }^{39}$

Some rulers' consorts managed to build on the specific functions attributed to them to broaden their participation in the practice of power. Katrin Keller's portrait of Anna of Saxony (1532-1585) shows how under the right circumstances, such as high rank and a good relationship with her husband, a determined consort could become engaged in a great variety of aspects of rulership. ${ }^{40}$ Anna built up an extensive network of correspondence with noblewomen of other courts of the Empire, and she used this network skilfully to arrange marriages and to refer people to court positions, as well as to share and expand her medical knowledge. ${ }^{41}$ She acted as a patron for artists and scientists, and was known as an successful intermediary for anyone who wished to petition the ruler. ${ }^{42}$ Her collaboration with her husband was so efficient that he appointed her to an official position within the treasury, which gave her influence well beyond what was customary for a ducal consort. ${ }^{43}$

Such collaborative ruling marriages were considered to be an ideal by contemporaries, and the celebration of the ruling couple as the idealized parents of their territory was a central mode for thinking about power. ${ }^{44}$ Nevertheless, couples had to tread a fine line between being seen as the embodiment of harmonious matrimony and being accused of gynocracy, which

\footnotetext{
39 On the symbolic and practical functions of the Frauenzimmer and access to it see also Maritz, 'Gender as a Resource of Power at the Early Modern Court', pp. 60-70; On the ruler's figurative access to the Frauenzimmer see C. Nolte, 'Verbalerotische Kommunikation, gut schwenck oder: Worüber lachte man bei Hofe? Einige Thesen zum Briefwechsel des Kurfürstenpaares Albrecht und Anna von Brandenburg-Ansbach 1474/75', in J. Hirschbiegel and W. Paravicini (eds.), Das Frauenzimmer: Die Frau Bei Hofe in Spätmittelalter und früher Neuzeit (Stuttgart, 2000), pp. 449-461, who discusses an interesting case of a ruler writing letters containing erotic humour to the Frauenzimmer, which were then read aloud, discussed and answered by his consort and her ladies-in-waiting.

40 Keller, Kurfürstin Anna von Sachsen (1532-1585), p. 26.

${ }^{41}$ Ibid., pp. 72-111; A. Rankin, Panaceia's Daughters: Noblewomen as Healers in Early Modern Germany (Chicago, III., 2013), ch. 1 'Noble Empirics', pp. 25-60 uses Anna as a key example of a noble healer and gives insights into the medical concerns of her correspondence.

42 Keller, Kurfürstin Anna von Sachsen (1532-1585), pp. 91-98.

${ }^{43}$ Ibid., pp. 115-119.

${ }^{44}$ See on this C. Opitz, 'Hausmutter und Landesfürstin', in R. Villari and A. Simon (eds.), Der Mensch des Barock (Frankfurt am Main, 1999), pp. 344-370, here pp. 357ff.; J. F. Harrington, 'Hausvater and Landesvater: Paternalism and marriage reform in sixteenth-century Germany', Central European History, 25 (March 1992), pp. 52-75., here p. 58.

44 Ibid., p. 6
} 
might prove to be very damaging. Furthermore, we need to be wary of reading the monogamous marriage constellation of the German-speaking court as a direct channel for the empowerment of noblewomen. The fulfilment of the representational function of the Landesmutter (mother of the territory), did not necessarily hinge on the personal freedom of action of the woman concerned. The case at hand is no exception in featuring a ruler's consort who was recognised by the court and her subjects as a loving Landesmutter, but who was granted very little sway by her husband over the design of her own household. ${ }^{45}$

\section{III: The Marriage of Duke Friedrich I. and Duchess Sibylla}

Duke Friedrich I (r.1593-1608) and Sibylla von Anhalt (1564-1614) were married in Stuttgart in 1581, about one year after Friedrich had met the sixteen-year old Sibylla at the court of Dessau and had been immediately attracted to her. ${ }^{46}$ The marriage was an important dynastic turning point in Friedrich's life. In June 1581, a month after the wedding celebrations, he was declared of age at twenty-three and he was given the territory of Mömpelgard to rule with his spouse. As far as we can tell from the correspondence between the couple, the first decade of their marital life appears to have been cordial. More importantly, it was also very fertile. ${ }^{47}$ Sibylla bore Friedrich fifteen children in as many years, and this was important in making him an attractive candidate for the succession to the dukedom when Ludwig died in 1593 without leaving any immediate male heirs. On her return to Stuttgart as duchess of Württemberg, Sibylla was wellplaced to fulfil the role of a Landesmutter. She was deeply religious and thus formed an important counter-weight to her husband, whose piety was occasionally doubted. ${ }^{48}$ She appointed the educated daughter of a local physician to help her run the court pharmacy in Stuttgart, and before long distilled medicines that were made widely available, thus positioning herself in the role of a care-giver for the entire territory of Württemberg. ${ }^{49} \mathrm{~A}$ sermon written on

\footnotetext{
45 This will be discussed below.

${ }^{46}$ Sauer, Herzog Friedrich I., p. 57-62.

47 The interesting correspondence conducted by the couple can be found under HStAS G 60 Bü 9.

48 See funeral sermons by E Grüninger, cited in: G. Raff, Das Haus Württemberg von Herzog Friedrich I. Bis Herzog Eberhard III.: Mit den Linien Stuttgart, Mömpelgard, Weiltingen, Neuenstadt am Kocher, Neuenbürg und Oels in Schlesien (Schwaigern, 2015²), pp. 8 (for Friedrich), 58-9 (for Sibylla).

49 On her role in the court pharmacy see: Rankin, Panaceia's Daughters, p. 13 and 29-30.
} 
the occasion of her death in 1614 stated that 'with her pious, ardent and continuous prayers she made herself into a wall and thus opposed many a crack, and so she helped many times to hold back the wrath of God' ${ }^{50}$

Despite Sibylla's ultimate success in fulfilling her dynastic and representative duties, she found herself progressively more constrained in her actions by Friedrich from the early 1590's onwards. Their relationship at that time was increasingly characterised by disruptions of communication and collaboration, which appear to have been rooted in Friedrich's more or less overtly practiced concubinage, as well as in his determined attempts to focus all decisionmaking power on himself. ${ }^{51}$ In August 1604 Sibylla was absorbed in the preparations for the wedding of her daughter Sibylla Elisabeth (1586-1606) to Johan Georg of Saxony (a grandson of Anna of Saxony), which was to take place in September of that year. During these weeks she wrote several long letters to Friedrich negotiating the preparations and from these it emerges that Friedrich wished to decide every last detail. For instance, Sibylla grudgingly conceded that she would take only five ladies-in-waiting to accompany her and her daughter, although she 'did not know how that would look' ${ }^{52}$ Friedrich further opposed her suggestions for the number and type of wedding wreaths. ${ }^{53}$ Eventually though, she went ahead and commissioned an unspecified gift for the bride and groom, without consulting Friedrich. Since he painstakingly inspected all expenses he eventually found out about this some months after the wedding and was outraged: 'we asked the jeweller who let us know ... that you signed the note yourself, and now we would like to know who gave you the power during this bridal procession to oversee this gift, [...] I only let you come as the bride mother' ${ }^{54}$ Friedrich further stated 'we feel like

\footnotetext{
50 G. Müller, Jacobs Burg Das ist. Ein Christliche Leichpredigt, von der seeligen Kinder Gottes bestendigen vnd vnvberwindlichen Vestung ... Frawen Sibylla, Hertzogin zu Wurte[m]berg vnd Teckh ... Gebornn Fürstin zu Anhalt ... welche den 16. tag Wintermonats zu Löwemberg ... entschlaffen ... (Mümpelgart, 1614), p. 2: 'hatt sie sich mit ihrem gleübigen inbrünstigen vnd vnableßigen gebett zur Mauren gemacht / vnnd gestellt wider manchem schweren Riß /vnnd hiemit den Zorn Gottes vil mahlen helffen zuruckh halten'; compare this to Bepler, 'Die Fürstin als Betsäule', pp. 249-252.

51 The decline of their amicable relationship is documented by the letters in HStAS G 60 Bü 9, also see: Sauer, Herzog Friedrich I., pp. 164-73.

52 HStAS, G 60 Bü 9, letter from Sibylla to Friedrich, 15 Aug. 1604.

53 HStAS G 60 Bü 9, letter from Sibylla to Friedrich, undated but connected by content.

${ }^{54}$ HStAS G 60 Bü 9, letter from Friedrich to Sibylla, 23 Jan. 1605, 'a[u]ch den jubilliren befragt, der vns a[u]ch angezeigt ... wie du da den zettel selber vnderschriben, nhun wolen wir gern wissen wer dir auf diser heimbfhurung gevhalt geben, dich diser schenkhung vnd verehrung anzunemen ... ich ...

dich nicht hab anders mitziehen lassen, als die praut mutter'.
} 
coming upstairs to you and mauling you so that in the future you will no longer be able to oppose our order so rudely'. ${ }^{55}$

This example shows how intensely preoccupied Friedrich was with controlling the finances of his wife and her household. The court treasury documents reveal that spending on the Frauenzimmer during Friedrich's reign was very low, averaging at only 69 Gulden and 12 Kreuzer a year. This figure was to jump to over twenty times this amount when Friedrich's son Johann Friedrich ascended to the throne and granted his wife much greater financial independence. 56

The degree to which Sibylla was removed from decision-making power - even where her own household was concerned - is unusual. ${ }^{57}$ It is not enough to reproach Friedrich for being a difficult and controlling husband, for such an interpretation only addresses the 'private life' of the couple and misses the political dimension of the marriage. What we see here is a territorial ruler who was aiming to concentrate governing authority in his own person, and for Friedrich that included undermining his wife's labour. He did this in a way that was similar to how he sought to undercut the political participation of the local estates with help from his male favourite, Matthäus Enzlin. It has been shown elsewhere that Friedrich was influenced in his political views by French ideas of monarchical rule, to which he had been exposed during the time he spent ruling the territory of Mömpelgard. It was during his reign there that Jean Bodin's Six Livres de la République were printed in German translation for the first time in the local officially mandated printshop. ${ }^{58}$ It is thus no stretch to imagine Friedrich reading the text and attentively noting Bodin's prescription for a strong male powerholder to guarantee political

\footnotetext{
55 Ibid., 'hett wir lust zu dir hinauf zu gehn vnd dich so zu trackhtiren, dz dich zu künfftig dergleichen nicht gelingen solt,weder vnseren befelh dich so gröblich zu verhalten'.

${ }^{56}$ This calculation was made on the basis of transcriptions of the Landschreiberei documents of the volumes HStAS A 256 Bd. 78-94 and Bd. 97-106, they were made available to me by Dr. Stefan Hanß. He is in the process of editing and translating these documents for publication under the prospective title of 'Crafting Courtly Culture in Early Modern Germany: Critical Online Edition of the Duke of Württemberg's Payments to Craftspeople, Stuttgart, 1592$1629^{\prime}$. I am very grateful to Dr. Hanß for sharing his work with me before publication.

${ }^{57}$ Compare for instance with Keller, Kurfürstin Anna von Sachsen (1532-1585), pp. 43-51; also C. Nolte, Familie, Hof und Herrschaft: das verwandtschaftliche Beziehungs- und Kommunikationsnetz der Reichsfürsten am Beispiel der Markgrafen von Brandenburg-Ansbach (1440 - 1530) (Ostfildern, 2005), p. 238.

58 Lorenz, 'Herzog Friedrich I. Von Württemberg (1557-1608)', p. 8; P. Rückert, Württemberg und Mömpelgard 600 Jahre Begegnung: Katalog zur Ausstellung des Hauptstaatsarchivs Stuttgart (Stuttgart, 2000), pp. 37-8.
} 
stability. ${ }^{59}$ In the end, the steps he proposed towards a more absolutist model of governance were cut short by his early death in 1608 . The reign of his son Duke Johann Friedrich and his wife Duchess Barbara Sophia reinstated closer collaboration between the ducal government and the estates and placed a renewed focus on the shared representational labour of the reigning couple.

\section{IV: Magdalena Möringer: A Female Favourite}

Where in the political configuration of Friedrich and Sibylla's reign are we to place Magdalena Möringer and the women in her care? A first indication of the prominence of their position is provided by the administrative energy that the Stuttgart court invested in their case. On the 30th of January 1608, less than a day after Friedrich's death, around thirteen women were arrested in various locations in Württemberg, and attempts were made to hold them accountable for the adultery they had allegedly committed with the late duke. This was a serious charge to make as in Württemberg adultery was a capital offense. ${ }^{60}$ The few surviving records from this stage of the prosecution show that most of the women were released again within a few days of their arrest. ${ }^{61}$ Only Magdalena Möringer remained in custody. For her, the early days of the year 1608 marked the beginning of an ordeal that was to stretch over the best part of a decade. ${ }^{62}$ At the time of her arrest, Möringer was aged 41. She had lived in Urach, a town not far from Stuttgart, for about six years in the house of Anna Emershöfer, a local widow. ${ }^{63}$ Together the two women had amassed a considerable estate that consisted of rich clothing, silver pieces, several servants, a carriage and two handsome brown horses. ${ }^{64}$ This

\footnotetext{
59 On Bodin's preoccupation with the male gender of the ideal ruler see C. Opitz-Belakhal, Das Universum des Jean Bodin: Staatsbildung, Macht und Geschlecht im 16. Jahrhundert, (Frankfurt am Main, 2006), esp. pp. 46f.

60 Though in practice it was difficult to impose the death penalty. See the discussion of court councillor Melchior Jäger on this point: HStAS A 48/10 Bü 3, Gutachten, doc. 36, $15^{\text {th }}$ August $1610,2 v$.

61 Sauer, Herzog Friedrich I. , p. 310.

${ }^{62}$ Möringer's imprisonment is well documented in legal and administrative records, as well as in an astonishing number of letters written by Möringer herself. Yet, it has so far received hardly any attention, except in an article by Ruth Blank in 2006, which described the contents of these sources. See R. Blank, 'Magdalena Möringer. Eine Gefangene auf der Festung Hohenurach', Zeitschrift für Württembergische Landesgeschichte., 65(2006), pp. 49-98, here esp. p. 50.

63 HStAS C 32933 I, a letter from Wilhelm von Remching (mayor of Urach), 26. March 1605.

64 HStAS C 32933 I, 'Inventarium', doc. 39, 20 March 1615.
} 
wealth is surprising since Möringer had originally arrived in Urach from Saxony as a humble butcher's widow. After her arrest, she had to witness the dismantling of her entire estate when Johann Friedrich and his mother Sibylla seized her assets. Möringer addressed many letters to them at this time, asking them not to take away all that was hers, to have mercy on her, to let her see her sons, and even to consider releasing her. ${ }^{65}$

Stuttgart did not change course, however, and kept Möringer imprisoned without officially levelling a charge against her or instigating a lawsuit. She was held in the fortress in Hohenurach for two years, then in 1610 it emerged that a charge had been filed at the Imperial Chamber Court of the Holy Roman Empire (Reichskammergericht) against Duke Johan Friedrich for wrongfully imprisoning Möringer. It is likely that Möringer instigated this lawsuit with the help of the legal guardian appointed to her, although she later denied this. ${ }^{66}$ The Imperial Chamber Court immediately judged Möringer to be held illegally, and began to petition Johan Friedrich to release her and to return to her at least parts of her estate. ${ }^{67}$ As this delicate case reached the highest legal institution in the empire it began to be a significant worry for Duke Johann Friedrich. His key councillor Melchior Jäger wrote another long report, in which he advised Johann Friedrich and his mother that it would not be possible to execute Möringer without drawing significant negative attention and he emphasised,

the great dangerous difficulties and inconveniences that could arise out of this for y[our] $\mathrm{p}$ [rincely] g[race] and the entire $\mathrm{p}$ [rincely] house of Württemberg, as well as your princely posterity, land and people (which should not be allowed to happen on behalf of this godless profligate woman). ${ }^{68}$

\footnotetext{
${ }^{65}$ All letters from HStAS, e.g. for an apology and the demand to show her mercy: A 4810 Bü 3, 19 May 1610, Möringer to duke Johann Friedrich; : A 4810 Bü 3, letter by Möringer, 4 September 1610, she states that she had been lead astray by the 'old woman', i.e. Anna Emershöfer, her reproaches to Emershöfer are expounded in an undated letter, A 48/10 Bü 2, doc. 86.

${ }^{66}$ At this time it was normal procedure for women in Württemberg to conduct any official legal or financial transactions through such a guardian (Kriegsvogt). HStAS A 48/10 Bü 3, doc. 4, 9th June 1610.

${ }^{67}$ A. Brunotte and R. J. Weber, Akten des Reichskammersgerichts im Hauptstaatsarchiv Stuttgart: Inventar des Bestands C3, vol. IV (Stuttgart, 2000), pp. 526-7.

${ }^{68}$ HStAS A 4810 Bü 3, Gutachten written by Jäger for Johann Friedrich and Sibylla, doc. 36, 15 Aug. 1610, 5r, 'die grosse gefährliche difficultäten vnd beschwehrlichaitten, so e.f.g. vnd dem ganzen $\mathrm{f}$ hauss Wirttemberg, auch dero firstlichen Posterität, Land vnd Leitten hierauss entstehen khendte (. dahin mans von dises gottlosen leichtferttigen weibs wegen nit kommen lassen solle.)'.
} 
Therefore he counselled threatening Möringer with an interrogation under torture in order to frighten her into dropping the lawsuit at the Reichskammergericht, since 'there is a general feeling at the imperial court, as at the Kammergericht, that people are rather amused over $\mathrm{y}$ [our] p[rincely] g[race]'s father's imbecility'. ${ }^{69}$ The records do not show whether Möringer was really threatened with torture and death, but she in any case refused to abandon her lawsuit. The duke and his advisors at this point spoke of Möringer's transgressions largely in financial terms. It was argued that her wealth had been confiscated in order to pay back creditors whom Möringer had wronged, and soon charges against her revolved around how she had obtained certain silver pieces and precious fabrics, rather than making any direct references to her alleged immoral behaviour. In 1614 Johann Friedrich and his mother decided to move Möringer to a hospice (Spital) in Gröningen, where she was meant to stay for the remainder of her life. ${ }^{70}$ Once Möringer arrived in the hospice, however, she fled the territory of Württemberg within weeks. She escaped to Speyer where the Imperial Chamber Court was located, and continued for a number of years her petition to regain some of her belongings. In this she was unsuccessful and she disappears from the records in 1618. At this point in time she would have been over 50 years of age, and she may have moved elsewhere or died after her prolonged imprisonment.

For the purposes of this study, it is most relevant to understand the conditions within Möringer's household while Friedrich was still alive. The sources present some problems of interpretation, since all references to Möringer and the women she lived with date from after her abrupt fall from grace. In general, Möringer was very careful to avoid the subject of her contact with the late duke as far as possible, and disavowed her relationships with the other women often in the strongest of terms. Nevertheless, it is possible to gain a glimpse of the dynamics of this female household through a careful reading of these documents.

Firstly, it is relevant to consider Urach, the location of the female household headed by Möringer. Urach was located about forty kilometres away from the court of Stuttgart. Although

\footnotetext{
${ }^{69}$ Ibid., 2r, 'hatt mann allberaitt verspihrt, dass mann sich, sowohl im kay. hofe, als bey dem Camergerichtt mitt obhochseeliggedachts e.f.g. herrn Vatters Imbecilität zimblich küzelt ...'.

70 See HStAS A 41 Bü 429, Kielmann and Broll et al. to Johann Friedrich17 June 1614,'Anbringen vnd Bedencken / der Möringerin Tranßlation, von hohenvrach in Spitaal zu Gröningen: Vnd ihr vnderhalltung daselbsten betreffend'.
} 
this was a considerable distance in seventeenth century terms, Duke Friedrich had a variety of reasons to gravitate towards this location. Firstly, Urach had symbolic meaning, for when Württemberg was divided between two brothers in 1441 it served as the second capital and residence besides Stuttgart. ${ }^{71}$ Secondly, Friedrich had invested heavily in manufacturing in the town since 1598, in order to turn it into a centre of damask and linen weaving. ${ }^{72}$ Thus, when Möringer arrived in Urach in 1602, it made sense for Friedrich to seek to establish a more permanent foothold in the town, which was integral to his aim of stimulating the export of manufactured goods from the duchy. ${ }^{73}$

The baptismal records for 1606 and 1607 show that Möringer stood as a godparent for a large number of children in Urach during these years. ${ }^{74}$ This suggests that although she was a widow of foreign origins she had by this time ascended to a position of trust and respect within the community. In this she was aided significantly by Duke Friedrich. In 1605 he decreed privileges for her, which meant that she was exempt from taxes and was granted the right to remain in Urach indefinitely with her two young sons. ${ }^{75}$ The 'noble, honourable and virtuous lady Magdalena Möringer' further received ducal letters of free passage that protected her on several journeys back to her home country of Saxony. ${ }^{76}$ Möringer identified with her adopted home and appears to have been as eager as the duke to promote its interests. In a letter to her former maid, written during her captivity, she recounted that she had cried for joy as Friedrich told her that he would come to Urach after Christmas in 1607, in order to organise a courtly dance there. ${ }^{77}$ The privileges she was awarded were extraordinary for a foreign widow of humble birth and means, and even though we cannot compare them to elevation of a male favourite to a high courtly office, they certainly comprise a tangible manifestation of the duke's favour, as well as an official reinforcement of Möringer's position.

\footnotetext{
71 W.-G. Fleck, Die Württembergischen Herzogsschlösser der Renaissance (Braubach, 2003), p. 44.

72 J. D. G. von Memminger, Beschreibung des Oberamts Urach, J. G. Cotta'sche Buchhandlung, (Stuttgart und Tübingen, 1831), pp. 107-108.

73 See Sauer, Herzog Friedrich I. von Württemberg 1557-1608, pp. 222f. for the privileges afforded to the Weaver's Guild in Urach in 1602, also ibid. pp. 203-33 for an overview of Friedrich's mercantilist policies.

74 Blank, 'Magdalena Möringer', p. 49.

75 HStAS C 32933 I,'Freisitzprivileg' for Möringer, signed by duke Friedrich, doc. 2, 11 May 1605.

76 HStAS C 32933 I, Willhelm von Remchingen attests to Möringer's good character, doc. 3, 26 March 1605, 'Edel. Ehr: vnd Thugentreiche Frauw Magdalena Möringerin'.

77 HStAS A 4810 Bü 3, undated letter to Maria Pirner.
} 
What is more, Möringer profited greatly in financial terms from her relationship with the duke. In an inventory dated 20th March 1615, when Möringer was fighting for the return of her goods from Speyer, she listed more than 300 items under 'Silver and gold', among which were many varieties of cups, a salt cellar, cutlery, and also rings, gems, and other jewellery. Her clothing included among many other items: coats made from costly black velvet, a brown fur with golden edgings worth more than $48 \mathrm{fl}$.; pairs of sleeves of damask and taffeta in silver, blue and black; and three bejewelled hats of black velvet, one stitched with pearls, a second with pearls and golden ornament, and a third with black pearls and gold. After six pages of items of clothing running to about one hundred items, the inventory turned to household objects. Here the relationship with Friedrich I. was not lost, since stowed away in Möringer's sewing desk were 'five silver tokens from when the duke was made a knight'. ${ }^{78}$ In a document separate from the official inventory, the chancellors Hormold and Broll informed Duke Johann Friedrich that among the silverware in Möringer's house 'there was a beautiful cup on which there were the images and coats of arms of three reigning dukes of Württemberg, Duke Ulrich, Duke Christoph, and Duke Eberhardt' ${ }^{79}$ This item was mentioned separately, since the chancellors assumed that the duke would not want to see it pass into the hands of 'dissolute people' ${ }^{80}$ Outside the house, Möringer's estate also included two valuable carriage horses with saddles for both men and women, as well as three cows and one calf, a large pig, 9 pairs of white pigeons, and a small white dog. Her larder was stocked with preserved fish and meat, lard, eggs, sauerkraut and 7 fuder of grain. ${ }^{81}$

This richly equipped household was thus openly linked to the late Duke Friedrich, and his generosity in this context emerges as particularly disproportionate when viewed alongside his attitude towards his wife Sibylla and her Frauenzimmer. The petitions and supplications written to Duke Johann Friedrich by the women formerly in Möringer's care reveal that they were used to being dressed almost as luxuriously as Möringer herself, and - willingly or not -

\footnotetext{
${ }^{78}$ In 1603 Friedrich I. Became a knight of the garter, presumably she speaks of commemorative tokens from this event. All items listed in, HStAS C 32933 I, 'Inventarium', doc. 39, 20 March 1615, here 12v, '5. silberne Zeichen, wie der Herzog zu Ritter ist geschlagen worden'.

79 HStAS A 48/10 Bü 2, doc. 44,19 July 1608, 'ein schöner Becher vorhanden, darauf drey Regirender herzogen zu Wirtemberg Herzog Vlrich, Herzog Christofs vnd Herzog Eberharts Bildtnuß vnd Wappen', original emphasis.

$80 \mathrm{lbid}$, 'liederlichen Leitten nit zuhanden komme'.

81 HStAS C 32933 I, 'Inventarium'doc. 39, 20 March 1615, 1 Fuder corresponds to around 1000 litres.
} 
Möringer appears to have played a central role in managing their lives and goods. ${ }^{82}$ One of the most revealing documents of the entire case was written by Philip Hirter, who came to act as advocate for Möringer at the Reichskammergericht in Speyer in the latter years of her legal battle. He displayed little sympathy for the memory of Duke Friedrich and addressed himself in his 1617 supplication directly to Emperor Matthias, stating that Möringer had borne the cost of 'the lying-in ... of the aforementioned Catharina von Miltitz, and thereafter of the burial of the dead little son in the church of Urach on ducal orders'. ${ }^{83}$ Although the wording is terse there is no suggestion that the child fathered by Friedrich had died of unnatural causes, but Hirter went on to say that Weickhmann, Ebner and von Miltitz received costly presents from 'the long dead prince, the father of the accused' and that Möringer 'had to give accommodation, and board, and maintenance [to them] beyond and against her will, in compliance with strict orders, which gave rise to this prosecution and explicit unlawful violence and [to her] innocent imprisonment by the Württemberg party .... ${ }^{84}$ : This vigorous defence of a non-noble and now non-wealthy woman in front of the Imperial Chamber Court is striking. Whilst this court was known for being more accommodating to female supplicants than many territorial courts of law, Duke Johann Friedrich was perhaps attacked with particular gusto at this point because he was in disfavour with the emperor because of his leading role in the Protestant Union. ${ }^{85}$

After having received Möringer's help during and after the birth of her illegitimate child, Catharina von Miltitz married Jost Weickhmann (a cousin of Ursula Weickhmann) in 1607. Jost was then made bailiff (Obervogt) of Blaubeuren, and thus the couple gained at least temporarily a secure position in ducal employment. A year later, Cordula Ebner married Adam

82 For instance see HStAS, A 48/10 Bü 1, doc. 49, 9 August 1608, supplication from Ursula Weickhmann to the duke Johann Friedrich asking for two golden chains and a diamond ring that are still being held; as well as doc. 21, 21 March 1608, Ursula Weickhmann's list of belongings she claims for herself, including golden jewellery and accessories, as well as clothes made from silk and taffeta.

${ }^{83}$ HStAS C 32933 II, Philipp Hirter to Emperor Matthias, doc. 81, 31 March, 1617, 8v: 'das ... gellt, nirgendt anderstwohin, alß zu bemellter Catharina von Miltitz zu donauwerth, ehe vnd sie sich an vorgedachten weickhmann verheyrathet, gehalltenen kindebeth, vnd hernacher zu Vrach, in der Kirch daselbsten, vf ernstlichen fürstlichen befehl angeordneter begrebnuß, erworbenen abgeleibten Söhnleins ... verwendet worden'. 84 Ibid.,7v-8r,'langst verstorbene fürst, des herrn beclagten herr vatter hochseeliger gedechtnuß, ...seine F.G. solche obgemellten dreyen frawen (. welche clagende Möringerin über vnd wider all iren willen auß ernstlichen befelch hausen vnd herbergen, auch Cost vndt Vnderhallt geben müßen, darauß diese verfolgung vnnd angelegt vnrechtmeßig gewallt, vnnd vnschuldigs gefengnuß von würtembergischer seiten ... entsprungen ist...'.

${ }^{85}$ S. Westphal, 'Frauen vor den höchsten Gerichten des alten Reiches: Eine Einführung', in S. Westphal (ed.), In eigener Sache: Frauen vor den höchsten Gerichten des Alten Reiches (Köln, 2005), pp. 1-17. 
von Wildnau, a former courtier of Friedrich's whose family had run into severe financial problems. ${ }^{86}$ Möringer lent the couple the enormous sum of 1800 Gulden for their marriage celebrations, which was never repaid to her, since she was already in custody at the time of the nuptials. ${ }^{87}$ Whilst she lived in Urach as a free woman, however, Möringer had remained central to the lives of the women in her care, even once their relationships with the duke had cooled off. In one of her written statements Möringer revealed that she took decisions relating to the staff of the household of Catharina Weickhmann, the 'Madam bailiff of Blaubeuren', even once she was married. ${ }^{88}$ Catharina appears to have welcomed her interference, for in a handful of letters, written before Duke Friedrich's death, she addressed Möringer with affection, describing her as 'my dear mother' and 'my motherly heart' and asking her for money or for help with travel arrangements. ${ }^{89}$. The female household in Urach thus emerges as a closelyknit community within which Möringer - despite her claims to the contrary - held a position of authority, which came to reach even the Obervogt household. From this perspective, Michael Koch's outraged words, cited at the beginning of this article, begin to seem more comprehensible.

Möringer's work in providing the women in her household with accommodation and board, as well as in managing their belongings and helping them to contract marriages shows some clear parallels to the role taken by a ruler's consort at the head of the courtly Frauenzimmer. What is more, her labour helped to contain the risk of allegations of sexual impropriety during Duke Friedrich's lifetime. She acted as a proxy for him, and thus prevented Friedrich from having to get involved in the incriminating business of burying an extramarital

\footnotetext{
${ }^{86}$ HStAS A 18 Bü 5, letters by Adam von Wildnau in relation to his employment at the court of Stuttgart: docs. 16 (29 July 1609), 3 (3 Sept. 1609), 36 (5 Oct. 1612), and from the 6th January 1609. Von Wildnau was again given employment at court after the death of Duke Friedrich I, which is interesting given that Johann Friedrich disapproved so strongly of the household of Magdalena Möringer. In his (ultimately successful) petitions for employment at court, von Wildnau cited his and his familiy's great financial need and the fact that they had been in receipt of support even in the reign of Duke Ludwig, and that Friedrich had continued this tradition.

${ }^{87}$ HStAS A 41 Bü 429, doc. 51 the borrower's note signed by Ebner and von Wildnau.

${ }^{8}$ HStAS A 48/10 Bü 2, doc. 84, no date, 'gewesen Öberu[o]gtin zu Blabeüren';See also C. Vanja, 'Auf Geheiss der Vögtin. Amtsfrauen in hessischen Höspitälern der Frühen Neuzeit', in H. Wunder and C. Vanja (eds.), Weiber, Menscher, Frauenzimmer: Frauen in der ländlichen Gesellschaft 1500 - 1800 (Göttingen, 1996), pp. 76-95, here pp. 84-87, who shows that a bailiff's wife was expected to share in the power of his office.

89 HStAS A 48/10 Bü 3, letters from Catharina Weickhmann to Möringer, 10 January 1608, and another without date: 'hertz liebe muotter', 'mein liebs mietterlichs herz'.
} 
son. Through such actions, Möringer was actively helping to manage the sexual reputation of the duke in the sense suggested by Katherine Crawford, who argues that it was crucial for regents to cultivate an image of themselves that underlined their masculine prowess, while at the same time avoiding the allegation of being excessively dependent on the charms of their mistresses. ${ }^{90}$

Möringer came closest to describing how she viewed her own position in the duke's family in a letter to her former maid Maria Pirner. ${ }^{91}$ Here Möringer recounted some of her interactions with the duke, and it is remarkable that she praised duke and duchesses' marriage while simultaneously inserting herself into their relationship. She insisted that

I know from his own lips that he loved his spouse dearly, [and] I am willing to swear at the risk of forfeiting my salvation, that he never in his life mentioned his spouse to me in negative terms, which is as true as it is that God still lives in Heaven. ${ }^{92}$

During a visit by ambassadors from England, Möringer records that she was present in the church in the city, but her narrative focuses on her fascination with the duchess: ${ }^{93}$

when the duchess went to the church with other princely men and women she held herself tall as if she were a girl of eighteen years ... God himself knows this is true, when the celebration was over the lord [Friedrich] asked me how I had liked everything and I told him that his wife had the most beautiful hands that I had ever seen on a woman and he laughed very loud and said that it was true by God ...94 In this curious account of the festivities, Möringer's experience of the day is closely associated with duchess Sibylla's extraordinary appearance. Möringer understood that her position as a female favourite of the duke placed her in tension with the role of the duchess. She was around

\footnotetext{
90 K. Crawford, The Sexual Culture of the French Renaissance (Cambridge, 2010), pp. 195-7, 230-3.

91 HStAS, A 48/10 Bü 3, no date.

92 Ibid., 2r, 'kan von im verstehen das Er sein gemal herzlich gelibt hat wil[I] auch so hoch schweren das ich nicht selig werd wan Er sein dag gegen mir ein mal hett sein gemal in vnguttenhet erwenet so war als gott im himel leb'. 93 Ibid.; Möringer is referring to the Stiftskirche in Stuttgart where in 1603 part of the festivities took place when Friedrich was inducted into the Order of the Garter by proxies sent by King James of England.

${ }_{94}^{4}$ HStAS, A 4810 Bü 3, undated letter to Maria Pirner, 2v, 'als so ist die herzig mit ander ferstlichen gemal vnd frauen zimer auch in die kirg gangen da ist sie so aufgricht gangen als ein metlein von achze Jaren...das wes gott im himel da das fest ist aus gewest so hat mich der her befragt wie mir als gefalen hat so hab ichs gesacht von sein gemal vnd so schen hend als ich mein dag an ein weisbilt [sic] hab ni geschen ist aber warlich war gewest so lacht [er] iberlaut sacht es ist war bey gott.'
} 
the same age as Sibylla, namely in her late thirties in this memory from 1603, but whereas she described Sibylla as extraordinarily youthful looking, she often signed her supplications for the mercy of Duke Johann Friedrich and the dowager duchess with 'Magdalena Möringer, poor, old widow'.

Thus the female household in Urach, with Möringer at its head, shows some significant parallels to the courtly Frauenzimmer led by the ruler's consort..$^{95}$ In the courtly women's quarters, the chastity of the young women had a crucial representational function, but both there and in Möringer's household it was common to arrange good marriages for the ladies-inwaiting at the end of their tenure. The already mentioned Catharina Weickhmann was born a von Miltitz, and thus belonged to a noble family from the Saxon city of Meißen. ${ }^{96}$ This was Möringer's hometown, and she visited it on a number of occasions between 1602 and 1608 . In fact, during the proceedings against Möringer, Catharina von Miltitz's mother wrote to Duke Johann Friedrich saying that she was shocked at what had happened, since she had assumed that Möringer had collected her daughter from her in order to bring her into the Frauenzimmer at the court of the duke of Stuttgart. ${ }^{97}$

Möringer herself was aware of the destabilising effect that her influence had on the representative relationship between the duke and the duchess. That is why in her supplications for mercy after her arrest, she defended herself by recollecting instances where she felt she had actually made attempts to foster a closer relationship between the ducal couple. In her letter to Maria Pirner she recalled how on one occasion she had told the duke that she thought it was 'a great adornment' when the ducal consort and her Frauenzimmer went hunting alongside the prince..$^{98}$ She wondered why Friedrich did not do this, since the elector of Heidelberg himself adhered to this practice. Möringer reported that Friedrich had agreed immediately and said that henceforth he would take the women, and that indeed he was sure

\footnotetext{
95 B. Kägler also argues that institutionalised mistresses pushed the consort aside to an extent, even if they did not live at court: Frauen Am Münchener Hof (1651-1756) (Kallmünz, 2011), esp. p. 293.

${ }^{6}$ C. Heinker, Miltitz (zu Batzdorf, Robschütz, Siebeneichen, Korbitz), Moritz Heinrich Freiherr von, in:

Sächsische Biografie, hrsg. vom Institut für Sächsische Geschichte und Volkskunde e.V., bearb. von Martina

Schattkowsky, Online-Ausgabe: http://www.isgv.de/saebi/ (03/08/17).

97 Blank, 'Magdalena Möringer', p. 62.

98 HStAS A 48/10 Bü 3, letter to Maria Pirner, 3r, 'gewaltiges grose ziret'.
} 
his wife would be strong enough to shoot a deer herself. ${ }^{99}$ Since Möringer wrote this during her imprisonment, we must read her words not merely as a private memory, but also as a defence strategy. In emphasising that she had actively attempted to reinforce the ducal marital relationship, she also reacted to the unspoken reproach that in fact she had done the opposite. For as discussed earlier, Heide Wunder has shown that political order depended on the hierarchical, but complementary roles of husband and wife. Any visible hindrance to the embodiment of these roles was most certainly a cause for concern.

If we compare the legal strategies used in the persecution of Möringer with those deployed for Matthäus Enzlin, we find that they were similar in both content and form. Both favourites had their charges reframed in several phases with the prosecution eventually settling on a narrative of financial misconduct. In an attempt to frighten the prisoners into cooperation, both were threatened with torture and even execution and in order to assure their silence, both defendants were forced to swear oaths (Urfehden) that they would comply with crippling stipulations in order to achieve an improvement of the conditions of their custody. ${ }^{100}$ Möringer agreed to work indefinitely in the Gröningen hospice, and Enzlin accepted an indefinite period of imprisonment for his crimes. Both prisoners at some point sought help from the Imperial Chamber Court of the Holy Roman Empire, which in turn was held against them. Their stories merely had different endings: as Enzlin was executed for treason after having broken his Urfehde in 1613; Möringer managed to escape from Gröningen one year later.

Beyond this, the prosecution of both Enzlin and Möringer served the young administration of Duke Johann Friedrich as a means to build consensus and to negotiate new relationships between the duke, his wife and his mother, as well as with Württemberg's estates. ${ }^{101}$ The Reichskammergericht decided immediately upon hearing the case in 1610 that Möringer was being held illegally, which makes it all the more remarkable that Johann Friedrich pursued it as far as he did. This was no trivial issue for him. The structures of power had been disrupted, and the prosecution of Möringer was a way of restoring them. To an extent, both

\footnotetext{
99 Ibid.

100 Asch, 'The Rise and Fall of Matthäus Enzlin (1556-1613)', p. 103; Möringer's Urfehde: HStAS A 41 Bü 429 , doc. 81.

101 Auge, 'Holzinger, Enzlin, Oppenheimer', p. 388, identifies consensus building as an important function that could stand behind accusations of corruption in attacks on male favourites.
} 
Möringer and Enzlin served as scapegoats and in reprimanding them so harshly the courtly administration of Johann Friedrich channelled complex issues of dissatisfaction with the previous ducal regime into a manageable conflict. As has been shown, a number of women were believed to have committed adultery with the late duke, but the attention of the ducal prosecution focused on Möringer alone. Her crime of procuration was viewed as a graver transgression than adultery by contemporary legal standards, but the fact that she was an unmarried foreigner in Württemberg must also have contributed to her being identified as a target by the new duke. In this way, the favourites discussed here also played an important role in the intergenerational politics of the court of Württemberg, at a time when the practice of power and rulership was an intensely personal affair.

\section{V: Conclusion}

Male and female favourites both came to be targets of overt attacks when they were perceived as threats to the balance of the God-given political order. Nevertheless, the category of gender should not be abandoned when studying them, for the actual practice of concubinage was highly gendered in the sense that men and women had very unequal access to it. Moreover, male and female favourites exercised influence over different aspects of the practice of power. Enzlin, for example, attracted the ill will of the incoming duke and his ministers because he had monopolised the role of advisor to Duke Friedrich I and thus undercut other councillors as well as the estates. The household of women in Urach under Möringer's guidance diverted financial and symbolic capital away from the courtly Frauenzimmer and the consort.

Duke Friedrich, who practiced this very specific form of concubinage, was a ruler who determinedly sought to expand the room for action and decision-making power that was traditionally accorded to the dukes of Württemberg and which was always hemmed in by the will of the local estates and the emperor. His choice to install a kind of alternative Frauenzimmer away from court, which housed some of his mistresses, can be read as forming a part of his broader campaign to emphasise the singular power of his position as duke. This is not to say that the influence of any and all cases of concubinage was limited to the power 
politics of the ruler's household. It has been shown that Madame de Pompadour, for instance, had a significant influence on foreign policy under the French king Louis $\mathrm{XV}$, and that her diplomatic labour resembled that of prominent courtly ministers. ${ }^{102}$ The context of the French court was, however, very different, and requires its own investigation into the gendering of concubinage. ${ }^{103}$ In order to escape the confining perspective of essentialised male lust and female opportunism, we must engage critically with the ways in which gender affected a princely person's ability to engage in concubinage and consider how the practice aligned itself with or challenged the structures of power at the early modern court. In the case at hand, neglecting this dynamic would mean failing to appreciate the political dimension of the household of the ruler's consort. Moreover, a gendered perspective on concubinage also takes us one step further, for it allows us to think about gender as a category of difference that was continuously reproduced and renegotiated at the early modern court, and that played a central and yet neglected role in the consolidation of dynastic power.

\footnotetext{
${ }^{102}$ E.K. Dade, Madame de Pompadour. Die Mätresse und die Diplomatie (Köln, 2010), pp. 199-214.

$103 \mathrm{Ibid} .$, p. 284, argues that a position such as the one held by Pompadour was likely only possible in the specific conditions of the late ancien régime.
} 